\title{
低温接合技術とフォトニクス応用
}

\section{Low-Temperature Bonding Technologies and Their Applications in the Field of Photonics}

\author{
マイクロメカトロニクス実装技術委員会
}

\section{1. はじめに}

近年, 機械・電子・光・化学・バイオなどに関わる新し い異種機能を集積した高付加価值デバイスの実現が期待さ れ，活発な研究が行われている ${ }^{1)}$ 。低温接合技術は，この ようなデバイス実現の鍵を握る重要な製造技術である。特 に, 研究用途から量産に対応できるさまざまな仕様の低温 接合装置が製品レベルまで達したこと, 開発されたデバイ ス性能の優位性から一部製品の量産化が始まったことで研 究開発が加速している。本稿では, 低温接合技術について 概説し, フォトニクス応用を中心に最近の開発動向につい て紹介する。

\section{2. 低温接合技術}

異種材料集積を実現する要素技術が，接合技術である。 半導体デバイスの製造に用いられる代表的な接合技術を表 1 に示す。直接接合と中間層接合で分類してある。これら の接合技術はそれぞれ一長一短があるが, 共通して進めら れてきた技術課題がプロセス温度の低温化である。デバイ スの熱損傷や実装時の熱応力を低減するという技術的な側 面と消費電力や $\mathrm{CO}_{2}$ 排出量の削減という環境配慮の側面の 両方から, 低温プロセスが強く求められてきた。

陽極接合技術 (Anodic bonding) は, シリコンと熱膨張係

表 1. 半導体デバイス製造に用いられる代表的な接合技術

\begin{tabular}{|c|c|c|c|c|}
\hline \multirow[b]{2}{*}{ 直接接合 } & ボンディング法 & 温度 $\left({ }^{\circ} \mathrm{C}\right)$ & $\begin{array}{l}\text { 気密 } \\
\text { 封止 }\end{array}$ & 特 徵 \\
\hline & \multirow{4}{*}{\begin{tabular}{|l} 
陽極接合 \\
フュージョンボン \\
ディング \\
プラズマ活性化接合 \\
表面活性化接合
\end{tabular}} & $300 \sim 500$ & 0 & 高接合強度 \\
\hline & & $600 \sim 1,200$ & $\bigcirc$ & 高接合強度 \\
\hline & & $150 \sim 400$ & 0 & \multirow{2}{*}{$\begin{array}{l}\text { 低温 } \\
\text { 低温, 高接合強度 }\end{array}$} \\
\hline & & 常温 150 & 0 & \\
\hline \multirow{9}{*}{ 中間層接合 } & \multicolumn{4}{|l|}{ 金属中間層 } \\
\hline & はんだ／共晶接合 & $180 \sim 450$ & $\bigcirc$ & \multirow{2}{*}{$\begin{array}{l}\text { 表面粗さ許容性 } \\
\text { 高温再溶融 }\end{array}$} \\
\hline & TLP 接合 & $180 \sim 300$ & $\bigcirc$ & \\
\hline & 熱圧着（拡散） & $300 \sim 500$ & 0 & \multirow{3}{*}{$\begin{array}{l}\text { 固相接合 } \\
\text { 低温, 固相接合 } \\
\text { 低温, 固相接合 }\end{array}$} \\
\hline & 超音波接合 & 常温～250 & 0 & \\
\hline & 表面活性化接合 & 常温 $\sim 150$ & 0 & \\
\hline & 絶縁中間層 & & & \multirow{3}{*}{$\begin{array}{l}\text { 低温, 表面粗さ許容性 } \\
\text { 表面粗さ許容性 }\end{array}$} \\
\hline & 有機接着剂 & 常温～300 & $x$ & \\
\hline & フリットガラス & $400 \sim 500$ & 0 & \\
\hline
\end{tabular}

数が近いホウケイ酸ガラスとシリコンを接合する技術であ り, $400^{\circ} \mathrm{C}$ 程度の温度でガラス側に数百 $\mathrm{V}$ の負電圧を印加 して, 静電引力により接合する。一般的にアルカリイオン の移動度が高くなる $300^{\circ} \mathrm{C}$ 以上で接合が行なわれるが, $250^{\circ} \mathrm{C}$ でも接合可能なガラスが開発されている。また，ガ ラスウェハの接合部に電極膜を形成し，接合部に電界を集 中させて低温で接合 $\left(200^{\circ} \mathrm{C}\right)$ するプロセスが開発されてい る。近年, 陽極接合可能な低温焼成セラミックス (Low Temperature Co-fired Ceramics) も開発され ${ }^{2)}$, MEMS (Micro Electro Mechanical Systems) のパッケージング技術として広 く利用されている。

フュージョンボンディング (Fusion bonding) は, 1986 年 に Lasky ${ }^{3)}$ が酸化膜を形成した Si 基板どうし, Shimbo ${ }^{4)} ら$ が $\mathrm{Si}$ 基板どうしの直接接合技術として検討し，主として SOI (Silicon on Insulator) ウェハの作製を目的に開発が進め られてきた。この接合は以下のように行われる。始めに ウェハの洗浄, 親水化処理を行い, 多数の水酸基 ( $\mathrm{OH}$ 基) を付着させる。ウェハ表面の水酸基間の水素結合は常温で も形成されるため, このように処理したウェハ表面同士を 常温で重ねるだけで二つのウェハの接合が可能である。特 に, 現在使用されている $\mathrm{Si}$ ウエハは表面が非常に平滑（rms 表面粗さ：0.2 nm 程度）に研磨されているため, 密着が自 発的に達成され，大きな加圧は不要である。しかしなが ら，水素結合により接合した試料はそのままでは十分な強 度が得られないため, 常温での貼り合わせの後に高温（〜 $1,200^{\circ} \mathrm{C}$ 程度）での熱処理が必要である。

一方, 化合物半導体基板へのフュージョンボンディング 技術の適用に関しては, 1990 年代になるまであまり行われ ていなかった。理由の一つは, ヘテロエピタキシーに関す る研究が活発に行われていたためである。ウェハボンディ ング技術は，必ずしも接合される材料間で格子定数や熱膨 張係数が同じである必要はなく，材料の組み合わせの自由 度が大きく, ヘテロエピタキシー成長困難な異種基板への デバイス作製を可能した。1990 年に Liau $5^{5)}$ が InP 基板と $\mathrm{GaAs}$ 基板の直接接合 $\left(650^{\circ} \mathrm{C}\right)$ を報告し, 化合物半導体の直 接接合法に大きな注目が集まった。1991 年, Lo ら ${ }^{6)}$ は GaAs 
基板上へ直接接合した $1.55 \mu \mathrm{m}$ 帯 $\mathrm{InP} / \mathrm{InGaAs}$ 系レーザを報 告した。以降, $\mathrm{Si}$ 基板上のレーザ素子 ${ }^{7)}$, 発光波長に対し て透明な基板に置き換えて高効率化を図った $\mathrm{AlGaInP} / \mathrm{GaP}$ LED (Light Emitting Diode) ${ }^{8}$, GaAs 基板上の AlAs $/ \mathrm{GaAs}$ ミ ラーを利用した長波長面発光レーザ素子 ${ }^{9}$ ，，Si をなだれ増 倍層として用いた $\mathrm{InGaAs} / \mathrm{Si}$ アバランシェ・フォトダイオー ド (APD: Avalanche Photoiode) $)^{10)}$ など, 多くの研究者によっ てさまざまな新規デバイスが創成された。

しかしながら，従来主に用いられてきたフュージョンボ ンディングは, 強固な接合を実現するには高温 $\left(>600^{\circ} \mathrm{C}\right)$ を 必要とするため, 接合強度とデバイス特性はトレードオフ の関係となり, デバイス特性の劣化, 熱膨張係数の違いか らウェハのそりや破壊が起こり, 低温直接接合法が強く望 まれていた。そのため, 接合プロセス自体を低温化する試 みも活発に研究が行われた。近年よく用いられているの が, ウェハ表面を酸素プラズマにより前処理するプラズマ 活性化接合法 (Plasma activation bonding) ${ }^{11)}$ である。処理し たウェハは強い親水性を示し，大気中で接合することによ り, $\mathrm{Si}$ や Si 酸化膜では $150 \sim 400^{\circ} \mathrm{C}$ 程度の熱处理で大きな 接合強度が得られる。

また，真空中で表面を洗浄化し，そのまま接合する表面 活性化接合法 (Surface activated bonding) ${ }^{12), 13)}$ では, 常温で も母材強度に匹敵する大きな接合強度が得られ, 残留応力 の極めて少ないプロセスが実現されている。表面活性化接 合法は, 物質の表面を覆っている酸化膜や有機物などの不 活性な層をイオンや高速原子線 (Fast atom beam: FAB) など の照射で取り除いて, 表面エネルギの高い活性な洗浄表面 を接触させることで, 原子間の凝着力を利用して常温また は低温で接合する方法である。これまで, $\mathrm{Si}, \mathrm{Ge}, \mathrm{GaAs}$, $\mathrm{InP}, \mathrm{GaN}$ などの半導体ウェ八接合が行われてきた。また, $\mathrm{LiNbO}_{3}$ と $\mathrm{Si}$ など熱膨張係数差の大きい組み合わせでもウェ 八スケール接合が可能である ${ }^{14)}$ 。ガラスなどの酸化物の接 合では, 強度が弱いが, Fe などの数 $\mathrm{nm}$ 以下の金属薄膜を 介して接合するナノ密着層による常温接合が提案されてい る ${ }^{15)}$ 。

中間層を介した接合は，金属抒よび絶縁中間層を介した 接合に分類される。電気的な接続が可能となる金属中間層 を介した接合には, Sn-Ag $\left(\mathrm{Sn}-3.5 \mathrm{Ag}: 221^{\circ} \mathrm{C}\right)$ や Sn-Ag-Cu (Sn-3.0-0.5Cu : 約 $217^{\circ} \mathrm{C}$ ) などのはんだ接合 (Solder bonding), $\mathrm{Au}-\mathrm{Sn}\left(\mathrm{Au}-80 \mathrm{Sn}: 280^{\circ} \mathrm{C}\right)$ や $\mathrm{Au}-\mathrm{Si}\left(\mathrm{Au}-6 \mathrm{Si}: 370^{\circ} \mathrm{C}\right)$ などの共晶 接合 (Eutectic bonding), Cu-Sn $\left(\mathrm{Sn}: 232^{\circ} \mathrm{C}\right)$ や Au-In (In: $\left.156^{\circ} \mathrm{C}\right)$ などの組み合わせで，一時的に溶融して金属間化合 物を形成する TLP (Transient Liquid Phase) 接合などがある。 Sn-Bi (Sn-58Bi: $\left.139^{\circ} \mathrm{C}\right)$ や Sn-In (Sn-52In: $\left.117^{\circ} \mathrm{C}\right)$ はんだは低 融点はんだとして用いられている。はんだ接合では, 表面 酸化膜を除去するために各種のフラックスが使用される場 合が多い。光応用では素子に付着したフラックスがレーザ の進路を妨げたり, 素子性能を劣化させるため, フラック
スフリーの接合が求められている。TLP 接合は一度合金化 すると融点が高くなるので, 後工程で溶融しない耐熱性が 求められる積層プロセスに適している。これら固液反応を 利用する接合法は，実装精度は固相接合に劣るが，ある程 度凹凸があっても接合することができ，表面粗さ許容性が 高い。一般に光素子の実装には, AuSn 共晶はんだが広く用 いられている。

また，金属の固相接合として, $\mathrm{Au}-\mathrm{Au}$ や $\mathrm{Cu}-\mathrm{Cu}$ などの熱 圧着 (Thermo-compression bonding) や拡散接合 (Diffusion bonding), ワイヤボンディングなどで使われている超音波 接合，金属同士の表面活性化接合がある。超音波接合は， 加熱，加圧に加えて超音波エネルギを印加することで，金 属接合を形成させる方法である。低温かつ短時間での接合 が可能であるが，大面積には適用できない。光素子の接合

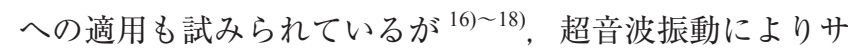
ブミクロンの高精度な位置決めが困難という課題がある。 また熱圧着による方法でも $300 \sim 500^{\circ} \mathrm{C}$ の長時間（数十分 以上）の加熱が必要である。近年, 低温・低荷重プロセス の観点から，金属サブミクロン粒子やナノ粒子を用いた低 温プロセスの研究開発 ${ }^{19)}$ やナノポーラス・スポンジ $\mathrm{Au}$ バ ンプ 20) の開発が活発に進められている。また, $\mathrm{Au}-\mathrm{Au}$ 表面 活性化接合に基づく光素子の高精度低温接合技術（接合温

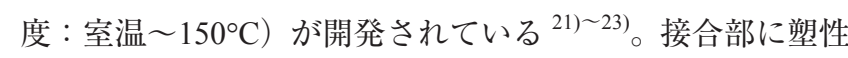
変形しやすい形状（マイクロ・ナノ構造）を付与すること が, 低温, 低荷重の点で有効である。

絶縁中間層を介した接合には，有機接着剤 (polymer adhesive bonding) や低融点ガラス紛体（フリット）を用いたフ リットガラス接合 (Flit Glass bonding) などがある。有機接 着剤には、エポキシ, UVエポキシ (SU8), ポリイミド, ベ ンゾシクロブテン (Benzocyclobutene: BCB), などが用いら れる。導電性が求められる場合には, $\mathrm{Ag}$ などの導電性フィ ラーとエポキシ樹脂などのベース樹脂からなる導電性接着 剂が用いられる。有機接着剤は, 表面粗さ許容性が高く, 比較的低温 $\left(\sim 300^{\circ} \mathrm{C}\right)$ で硬化できる。一方, 有機接着剂 を用いたときに問題になるのがガスの放出である。ガス放 出によるコンタミネーションによって特性が影響を受ける ことがある。また多くの有機系材料は水分を吸収するた め, 気密封止には適さない。

\section{3. デバイス応用への取り組み}

以下，近年進められている，低温接合技術を用いた各種 フォトニクス応用について紹介する。

\section{・裏面照射型 CMOS イメージセンサ}

表面入射型イメージセンサでは，配線層側（表面側）か ら入射光が入射されるのに対し, 裏面照射型イメージセン サでは，配線層とは反対側（毫面側）から入射光が入射さ れる。したがって裏面照射型イメージセンサでは，入射光 の一部が配線層により遮光されてしまうようなことがない 


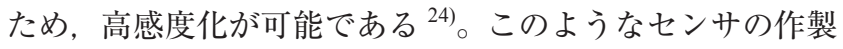
には，シリコン基板上にフォトダイオード，配線層を作製 して, 配線層の上部に別の支持基板を接合し, 裏側からシ リコン基板を薄く研磨するプロセスが行われる。デバイス にダメージを与えない低温接合技術が使用される。上部の pn 接合フォトダイオードアレイと下部の CMOS 読み出し 回路を $\mathrm{Au}$ 先鋭マイクロバンプで接続した裏面照射型 CMOS イメージセンサも試作されている ${ }^{25)}$ 。

\section{・画素並列信号処理 3 次元構造撮像デバイス}

高精細で高フレームレートな次世代小型カメラの実現に 向けて, 3 次元構造を採用したイメージセンサの開発が行 われている ${ }^{26)}$ 。各画素で生成された信号は, それぞれの画 素の直下に設けられた信号処理回路で同時に処理される。 基板の積層と層間の配線接続を行うため, デバイスにダ メージを与えない高精度な低温接合技術が求められる。 $\mathrm{SiO}_{2}$ 層間絶縁膜内に $\mathrm{Au}$ 電極を埋め込んだ後に表面を平坦 化して, ハイブリッド接合すすることで, 上下基板間の信 号伝達が可能となることが示されている ${ }^{27) 。 ~}$

\section{・多接合型化合物半導体太陽電池}

単接合太陽電池の限界を超える高い変換効率を実現でき る多接合型太陽電池の開発が精力的に進められている。高 効率の観点からは, 多接合構造に用いられる各材料の禁制 帯幅の組み合わせが重要になるが, 格子整合系においては 材料選択の幅が限られるため, 格子不整合系を実現できる 低温接合技術が期待されている。フラウンホーファー太陽 エネルギーシステム研究所では, 表面活性化接合を用いた $\mathrm{GaInP} / \mathrm{GaAs} / \mathrm{Si}$ 太陽電池の試みがなされている ${ }^{28)}$

\section{- 遠赤外線検出器}

遠赤外線およびテラヘルツ帯（50～300 $\mu \mathrm{m}$ 帯）の光検出 器として, Ge 系 Blocked Impurity Band (BIB) 型検出器が期 待されている。BIB 型検出器は, ガリウム $(\mathrm{Ga})$ などの不純 物を高濃度にドープした吸収層と, そこで発生する暗電流 を遮断するための高純度ブロック層の二層構造からなる。 急峻な不純物濃度勾配を有する二層構造 Ge ウェハを実現 するために $\mathrm{Ge} / \mathrm{Ge}$ 表面活性化常温接合が試みられている ${ }^{29)}$

\section{- 3 次元構造光マイクロエンコーダ}

半導体レーザやフォトダイオードなどの光素子を高精度 に表面実装した基板をさらに高精度に積層していくことに より作製した 3 次元構造の光マイクロエンコーダが実現さ れている ${ }^{30)}$ 。複数回の加熱プロセスで, 素子が劣化しない ように $\mathrm{Au}-\mathrm{Au}$ 表面活性化接合による低温接合技術 $\left(150^{\circ} \mathrm{C}\right)$ が用いられている。

\section{・マイクロセンサのパッケージング}

半導体レーザを利用する光デバイスは, 使用環境からの 湿度などの影響を防ぐために, 最終的に不活性ガスを封入 した気密封止パッケージングが求められる。パッケージン グは最終工程であるため, チップの許容温度以下で行なわ れる必要がある。プラズマ活性化接合や表面活性化接合な
どの低温接合プロセスの適用も試みられている ${ }^{31)}$ 。

\section{・CMOS ドライバ IC 上の AIGaAs LED}

$\mathrm{GaAs}$ 基板上に形成する厚さ約 $2 \mu \mathrm{m}$ の LED エピタキシャ ル層を基板から剥離して $\mathrm{Si}$ の CMOS チップの上に接合し たLED プリントヘッドが開発され，量産されている。 $+70^{\circ} \mathrm{C}$ の高温放置や $-20^{\circ} \mathrm{C}$ の低温放置, さらに $+85^{\circ} \mathrm{C} /-40^{\circ} \mathrm{C}$ の温度サイクルにおいて LED 特性に大きな変化が無いこと が示されている ${ }^{32)}$ 。

\section{・高放熱構造高出力半導体レーザ}

半導体素子 (発光領域) と高熱伝導基板が近接した高放 熱構造光デバイスを実現するために，直接遷移型化合物半 導体の $\mathrm{GaAs}$ と $\mathrm{Cu}$ よりも大きな熱伝導率 $(490 \mathrm{~W} / \mathrm{mK})$ を有 する IV-IV 族化合物半導体の炭化ケイ素 $(\mathrm{SiC})$ を表面活性化 接合技術により直接常温で張り合わせた高放熱構造が提案 されている ${ }^{33)}$

\section{・SOI 基板上の InP 系半導体レーザ}

LSI 内光配線をめざし，Si を積極的にフォトニクスデバ イスに利用するシリコンフォトニクスが注目を集めてい る。 $\mathrm{Si}$ 細線導波路を形成した SOI ウェハと $\mathrm{InP}$ 系レーザウェ 八をプラズマ活性化接合や表面活性化接合などの低温接合 技術を用いて接合した，エバネッセント結合型レーザが開 発されている ${ }^{34) ~ 36) 。 ~}$

\section{- $\mathrm{Si}$ 基板上の $\mathrm{LiNbO}_{3}$ 導波路}

大きな電気光学定数 (ポッケルス定数) ・ 非線形光学定数 を有する $\mathrm{LiNbO}_{3}$ は, 高速・広帯域光変調器, 擬似位相整 合を用いた波長変換素子, 位相変調器, 光電界センサなど 光通信からセンサまで広範な分野で使用されている。 $\mathrm{Si}$ 基 板上に導波路や分極反転構造を施した $\mathrm{LiNbO}_{3}$ チップを高 精度低温接合する試みが行われている ${ }^{37), 38) 。 ま た, ~ S i ~ フ ゚ ~}$ ラットフォーム上に導波路型 PPLN (Periodically poled lithium niobate) と近赤外半導体レーザを表面活性化接合により実装 した SHG (Second Harmonic Generation) 緑色レーザモジュー ルが開発されている ${ }^{39)}$ 。

\section{・Si 導波層を有する導波路形光アイソレータ}

セリウム置換イットリウム鉄ガーネット (Ce:YIG) チップ を $\mathrm{Si}$ 導波路上に表面活性化接合した導波路型光アイソレー 夕が実現されている ${ }^{40)}$ 。 $\mathrm{Si}$ 層と $\mathrm{Ce}: \mathrm{YIG}$ 層を, $\mathrm{BCB}$ などの 中間層を介して接合する場合には, 接着層の厚さを数十 $\mathrm{nm}$ 以下に抑える必要があり, 直接接合技術が用いられている。

\section{・光通信用波長フィルター}

温度特性フリーエタロンフィルタの開発が行われてい る。水晶ウェハを数原子層から数 $10 \mathrm{~nm}$ 程度の薄い活性な 金属薄膜を用いて常温で接合（原子拡散接合）することに より, 精密な接合厚みの管理が可能となり, 高精度なエ夕 ロンフィルタが実現されている ${ }^{41)}$ 。

\section{・波長変換デバイス}

深紫外光レーザ光を高効率に発生させるための波長変換 デバイスが実現されている ${ }^{42)}$ 。ここでは，波長変換材料 
$\beta-\mathrm{BaB}_{2} \mathrm{O}_{4}(\mathrm{BBO})$ の結晶プレートをプレート内の結晶軸の向 きを周期的に反転させながら順に表面活性化により接合し た積層体が用いられている。

\section{4. おわりに}

低温接合技術について述べ, 最近のフォトニクス応用の 進展について紹介した。接合および実装プロセスの低温化 は，異種材料を集積した次世代高機能デバイスの実現に必 須であり，省エネルギプロセスの観点からも将来ますます 重要になってくると考えられる。今後, 接合界面の評価な どの基礎的な解明とともに信頼性の評価なども推し進めて いく必要がある。低温接合技術が多方面へと展開され，さ まざまな高機能フォトニクスデバイスが創出されることを 期待したい。

文責・日暮栄治 / 東京大学

(2013.11.12- 受理)

\section{文献}

1）益 一哉, 年吉 洋, 町田克之監修: “異種機能デバイス集 積化技術の基礎と応用一MEMS, NEMS，センサ，CMOSLSI の融合一, ”シーエムシー出版, 2012

2）毛利 護，江刺正喜，田中秀治：“LTCC 基板による MEMS ウエハレベルパッケージング技術, ”電気学会論文誌 E（セ ンサ・マイクロマシン部門誌), Vol. 132, No. 8, pp. 246253,2012

3) J. B. Lasky: "Wafer bonding for silicon-on-insulator technologies," Appl. Phys. Lett., Vol. 48, pp. 78-80, 1986

4) M. Shimbo, K. Furukawa, K. Fukuda, and K. Tanzawa: "Siliconto-silicon direct bonding method," J. Appl. Phys., Vol. 60, pp. $2987-2989,1986$

5) Z. L. Liau and D. E. Mull: "Wafer fusion: A novel technique for optoelectronic device fabrication and monolithic integration," Appl. Phys. Lett., Vol. 56, pp. 737-739, 1990

6) Y. H. Lo, R. Bhat, D. M. Hwang, M. A. Koza, and T. P. Lee: "Bonding by atomic rearrangement of InP/InGaAsP $1.5 \mu \mathrm{m}$ wavelength lasers on GaAs substrates,” Appl. Phys. Lett., Vol. 58, pp. $1961-1963,1991$

7) Y. H. Lo, R. Bhat, D. M. Hwang, C. Chua, and C.-H. Lin: "Semiconductor lasers on Si substrates using the technology of bonding by atomic rearrangement," Appl. Phys. Lett., Vol. 62, pp. $1038-1040,1993$

8) F. A. Kish, F. M. Steranka, D. C. DeFevere, D. A. Vanderwater, K. G. Park, C. P. Kuo, T. D. Osentowski, M. J. Peanasky, J. G. Yu, R. M. Fletcher, D. A. Steigerwald, M. G. Craford, and V. M. Robbins: "Very high-efficiency semiconductor wafer-bonded transparent-substrate $\left(\mathrm{Al}_{\mathrm{x}} \mathrm{Ga}_{1-\mathrm{x}}\right)_{0.5} \mathrm{In}_{0.5} \mathrm{P} / \mathrm{GaP}$ light-emitting diodes,” Appl. Phys. Lett., Vol. 64, pp. 2839-2841, 1994

9) D. I. Babic, K. Streubel, R. P. Mirin, N. M. Margalit, J. E. Bowers,
E. L. Hu, D. E. Mars, L. Yang, and K. Carey: "Room-temperature continuous-wave operation of $1.54-\mu \mathrm{m}$ vertical-cavity lasers," IEEE Photon. Tech. Lett., Vol. 7, 1225-1227, 1995

10) A. R. Hawkins, T. E. Reynolds, D. R. England, D. I. Babic, M. J. Mondry, K. Streubel, and J. E. Bowers: "Silicon heterointerface photodetector," Appl. Phys. Lett., Vol. 68, pp. 3692-3694, 1996

11) S. N. Farrens, J. R. Dekker, J. K. Smith, and B. E. Roberds: "Chemical Free Room Temperature Wafer To Wafer Direct Bonding,” J. Electrochem. Soc., Vol. 142, pp. 3949-3955, 1995

12）赤池正剛, 舟久保熙康：“超高真空中における金属の常温圧 接,”真空, Vol. 23, pp. 455-464, 1980

13) T. Suga, Y. Takahashi, H. Takagi, B. Gibbesch, and G. Elssner: "Structure of Al-Al and Al- $\mathrm{Si}_{3} \mathrm{~N}_{4}$ interfaces bonded at room temperature by means of the surface activation method," Acta Metall. Mater., Vol. 40, pp. S133-S137, 1992

14) H. Takagi, R. Maeda, and T. Suga: "Room-temperature wafer bonding of $\mathrm{Si}$ to $\mathrm{LiNbO}_{3}, \mathrm{LiTaO}_{3}$, and $\mathrm{Gd}_{3} \mathrm{Ga}_{5} \mathrm{O}_{12}$ by Ar-beam surface activation," J. Micromech. Microeng., Vol. 11, pp. 348 352,2001

15) M. M. Howlader, T. Suga, and M. J. Kim: “A novel bonding method for ionic wafers," IEEE Trans. Adv. Packag., Vol. 30, No. 4, pp. 598-604, 2007

16) J. L. Joppe, A. J. T. de Krijger, and O. F. J. Noordman: "Hybrid integration of a laser diode and a monomode high contrast slab waveguide on silicon," Electron. Lett., Vol. 27, pp. 162-163, 1991

17) A. Ambrosy, H. Richter, J. Hehmann, and D. Ferling: "Silicon motherboards for multichannel optical modules," IEEE Trans. Compon. Packag. Manuf. Technol. A, Vol. 19, pp. 34-40, 1996

18) T. S. McLaren, S. Y. Kang, W. Zhang, T. H. Ju, and Y. C. Lee: "Development of a Thermosonic Bonding Process for an 8 x 8 VCSEL Array Based Optical Transceiver," IEEE Trans. Compon. Packag. Manuf. Technol. B, Vol. 20, pp. 152-160, 1997

19）小柏俊典，涉谷忠弘，宮入正幸，藤澤良知，鶴見和則，于 強：“サブミクロン $\mathrm{Au}$ 粒子焼結体を用いた低温接合技術,” エレクトロニクス実装学会誌, Vol. 10, No. 7, pp. 560-566, 2007

20) H. Oppermann and L. Dietrich: "Nanoporous gold bumps for low temperature bonding, Microelectronics Reliability," Vol. 52, pp. $356-360,2012$

21) E. Higurashi, T. Imamura, T. Suga, and R. Sawada: “Low temperature bonding of laser diode chips on Si substrates using plasma activation of Au films," Photon. Tech. Lett., Vol. 19, pp. 1994-1996, 2007

22) R. Takigawa, E. Higurashi, T. Suga, and R. Sawada: "RoomTemperature Bonding of Vertical-Cavity Surface-Emitting Laser Chips on Si Substrates Using Au Microbumps in Ambient Air," Applied Physics Express, Vol. 1, 112201, 2008

23) E. Higurashi, T. Fukunaga, and T. Suga: "Low-temperature bonding 
of $\mathrm{GaN}$ on Si using a nonalloyed metal Ohmic contact layer for GaN based heterogeneous devices," IEEE Journal of Quantum Electronics, Vol. 48, pp. 182-186, 2012

24) H. Wakabayashi, K. Yamaguchi, M. Okano, S. Kuramochi, O. Kumagai, S. Sakane, M. Ito, M. Hatano, M. Kikuchi, Y. Yamagata, T. Shikanai, K. Koseki, K. Mabuchi, Y. Maruyama, K. Akiyama, E. Miyata, T. Honda, M. Ohashi, and T. Nomoto: "A 1/2.3-inch 10.3Mpixel 50frame/s Back-Illuminated CMOS image sensor," Proceedings of International Solid-State Circuits Conference (ISSCC), pp. 410-411, 2010

25）浅野種正：“先鋭バンプを用いた異種材料・機能のマイクロ 接合技術, ”電子情報通信学会論文誌 C, Vol. J95-C, No. 8, pp. $148-155,2012$

26) 後藤正英, 萩原 啓, 井口義則, 大竹 浩, 更屋拓哉, 年 吉 洋, 平本俊郎：“撮像デバイスの 3 次元構造化に向けた 基板の深さ方向に信号伝達可能な MOSFET の試作, ”第 4 回集積化 MEMS シンポジウム講演論文集, IM3-3, pp. 6568,2012

27) 萩原 啓, 後藤正英, 大竹 浩, 井口義則, 更屋拓哉, 年 吉 洋, 日暮栄治, 平本俊郎：“表面活性化処理を用いた金 属／絶縁体混在基板の直接接合,” 2013 年春季第 60 回応用 物理学会春季学術講演会講演予稿集, 29a-G7-5 22-005, 2013

28) S. Essig, K. Derendorf, E. Oliva, A. Wekkeli, J. Benick, M. Hermele, G. Siefer, A. W. Bett, and F. Dimroth: Development of GaInP/GaAs/Si Solar Cells using Surface Activated Wafer Bonding, 12th International Symposium on Semiconductor Wafer Bonding: Science, Technology and Applications, 222th Electrochemical Society Fall Meeting, October 7-12, Honolulu, Hawaii, 2012

29）日暮栄治, 須賀唯知, 土井靖生, 瑻迫 巌: “遠赤外線検出 器応用をめざした Ge ウェハの常温直接接合技術, " OPTRONICS, Vol. 32, No. 379, pp. 93-97, 2013

30) E. Higurashi, D. Chino, T. Suga, and R. Sawada: "Au-Au SurfaceActivated Bonding and Its Application to Optical Microsensors with 3-D Structure," IEEE Journal of Selected Topics in Quantum Electronics, Vol. 15, pp. 1500-1505, 2009

31) S. Yamamoto, E. Higurashi, T. Suga, and R. Sawada: "Lowtemperature hermetic packaging for microsystems using $\mathrm{Au}-\mathrm{Au}$ surface-activated bonding at atmospheric pressure environment," J. Micromech. Microeng., Vol. 22, 055026, 2012

32）荻原光彦, 藤原博之, 鈴木貴人, 猪狩友希, 森崎誠司, 佐 久田昌明：“エピフィルムボンディングによる異種材料の高 密度集積技術, ”電子情報通信学会論文誌 C, Vol. J91-C, pp. 586-594, 2008

33) E. Higurashi, K. Nakasuji, and T. Suga: "Room-Temperature Direct Bonding of GaAs and $\mathrm{SiC}$ Wafers for Improved Heat Dissipation in High-Power Semiconductor Lasers," International Conference on Electronics Packaging (ICEP 2013), April 10-12, 2013, Osaka,
Japan, TD3-4, pp. 350-354, 2013

34) A. W. Fang, H. Park, Y. Kuo, R. Jones, O. Cohen, D. Liang, O. Raday, M. N. Sysak, M. J. Paniccia, and J. E. Bowers: "Hybrid silicon evanescent devices," Materials Today, Vol. 10, pp. 28-35, 2007

35) Y. Hayashi, R. Osabe, K. Fukuda, Y. Atsumi, J. H. Kang, N. Nishiyama, and S. Arai: "Low threshold current density operation of a GaInAsP/Si hybrid laser prepared by low-temperature $\mathrm{N}_{2}$ plasma activated bonding,” Jpn. J. Appl. Phys., Vol. 52, 060202, 2013

36) L. Li, A. Higo, E. Higurashi, M. Sugiyama, and Y. Nakano: "SOI Platform and III-V Integrated Active Photonic Device by Direct Bonding for Data Communication," Proceedings of 3rd IEEE International Workshop on Low Temperature Bonding for 3D Integration (LTB-3D), p. 87, 2012

37) R. Takigawa, E. Higurashi, T. Suga, and T. Kawanishi: "Passive Alignment and Mounting of $\mathrm{LiNbO}_{3}$ Waveguide Chips on $\mathrm{Si}$ Substrates by Low-Temperature Solid-State Bonding of Au," IEEE Journal of Selected Topics in Quantum Electronics, Vol. 17, pp. $652-658,2011$

38) R. Takigawa, E. Higurashi, T. Suga, and T. Kawanishi: “Air-gap structure between integrated $\mathrm{LiNbO}_{3}$ optical modulators and micromachined Si substrates," Optics Express, Vol. 19, pp. 15739-15749, 2011

39）依田 薰, 井出昌史，野崎孝明，深谷新平：“表面活性化接 合技術を用いた Si プラットフォーム型ファイバーピグテイ ルレーザーモジュール,” OPTRONICS, Vol. 32, No. 379, pp. 98-103, 2013

40) Y. Shoji, M. Ito, Y. Shirato, and T. Mizumoto: "Surface Activated Bonding of $\mathrm{Si} / \mathrm{Ce}$ YYIG for Waveguide Optical Isolators," Proceedings of 3rd IEEE International Workshop on Low Temperature Bonding for 3D Integration (LTB-3D), p. 95, 2012

41）島津武仁, 魚本 幸, 今 一恵, 若林小太郎, 大場健司, 古堅由紀子：“原子拡散接合法によるウェハ室温接合技術と エタロンフィルタへの応用, ” OPTRONICS, Vol. 32, No. 379, pp. $88-92,2013$

42) 庄司一郎：“低温接合技術による高機能レーザおよび波長変 換デバイスの開発,” OPTRONICS, Vol. 32, No. 379, pp. 78 82,2013

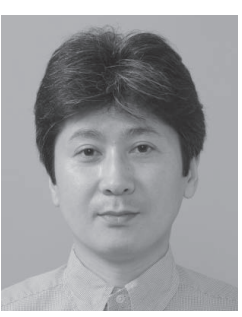

日暮栄治（ひぐらし えいじ）

著者紹介

東京大学先端科学技術研究センター准教授。1991 年東北大学大学院博士前期課程修了。博士（工 学)。光実装技術, 低温接合技術, 鉛フリーはん だバンプ形成技術，光マイクロシステムの研究に 従事。2002 年電気学会センサマイクロマシンシシ ポジウム五十嵐賞, 2003 年大川出版賞, 2008 年 市村学術賞貢献賞, 2011 年電気学会「センサ・マ イクロマシンと応用システム」シンポジウム最優 秀技術論文賞など受賞。エレクトロニクス実装学 会, 精密工学会, 電気学会, 応用物理学会, 電子 情報通信学会, IEEE 各会員。 